\title{
Penggunaan Model Pembelajaran Think-Talk-Write Sebagai Upaya Meningkatkan Prestasi Belajar Bahasa Indonesia
}

\author{
Ni Luh Ketut Rumiti ${ }^{1}$ \\ ${ }^{1}$ SD Negeri 1 Serongga, \\ Gianyar, Indonesia \\ email: rumiti69@gmaill.com
}

\begin{abstract}
Abstrak
Siswa yang berlajar di kelas VI, pada semester I, tahun pelajaran 2018/2019 SD Negeri 1 Serongga, dijadikan objek penelitian yang bertujuan untuk mencapai peningkatan prestasi belajar. Data yang diupayakan untuk diperoleh dikumpulkan dengan tets hasil belajar. Setelah diperoleh data, Ialu dilakukan analisis menggunakan analisis deskriptif. Setelah pelaksanaan tindakan, data yang penulis dapatkan menunjukkan peningkatan yang baik, dari awalnya baru mencapai rata-rata 69,59, pada siklus I meningkat menjadi 74,86 dan pada siklus II meningkat menjadi 81,21. Dengan perolehan peningkatan hasil tersebut dapat disampaikan bahwa dengan menerapkan Model Pembelajaran Think-Talk-Write dapat meningkatkan prestasi belajar Bahasa Indonesia siswa kelas VI SD Negeri 1 Serongga.
\end{abstract}

Kata Kunci: Model Pembelajaran Think-Talk-Write, Prestasi Belajar Siswa.

\begin{abstract}
Students studying in grade VI, in semester I, 2018/2019 school year SD Negeri 1 Serongga, are used as research objects that aim to achieve increased learning achievement. The data that was sought to be obtained were collected by means of learning outcomes. After obtaining the data, then analyzed using descriptive analysis. After the implementation of the action, the data that the writer got showed a good increase, from the beginning it only reached an average of 69.59 , in the first cycle it increased to 74.86 and in the second cycle it increased to 81.21. By obtaining an increase in these results, it can be said that applying the Think-Talk-Write Learning Model can improve the Indonesian learning achievement of grade VI students of SD Negeri 1 Serongga.
\end{abstract}

Keywords: Think-Talk-Write Learning Model, Student Learning Achievement.

\section{Pendahuluan}

Dalam era pembangunan dewasa ini makin lama makin kita rasakan pentingnya berkomunikasi baik antar anggota masyarakat maupun antar kelompok masyarakat. Alat komunikasi yang ampuh adalah bahasa. Dengan bahasa, manusia sebagai makhluk sosial dapat berhubungan satu sama lain secara efektif dan dapat menyatakan perasaan, pendapat bahkan dengan bahasa kita dapat berpikir dan bernalar. Bahasa juga memungkinkan manusia untuk saling berhubungan, saling berbagi pengalaman, saling belajar dari yang lain, dan untuk meningkatkan kemampuan intelektual dan kesusasteraan merupakan salah satu sarana untuk menuju pemahaman tersebut (Depdiknas 2004: 2). Oleh sebab itu, agar komunikasi berjalan dengan lancar, kita perlu terampil berbahasa baik lisan maupun tulis. Suatu komunikasi dikatakan berhasil apabila pesan yang disampaikan dapat dipahami dengan baik oleh penyimak suatu makna atau maksud.

Setiap keterampilan itu erat pula berhubungan dengan proses-proses berpikir yang mendasari bahasa. Bahasa seseorang mencerminkan pikirannya. Seseorang yang terampil berbahasa maka jalan pikirannya semakin cerah dan jelas. Keterampilan hanya dapat

\footnotetext{
${ }^{*}$ Corresponding author.

Received 03 Februari 2020; Accepted 31 July 2020; Available online 1 September 2020 (C) 2020 MPI. All Rights Reserved
} 
diperoleh dan dikuasai dengan jalan praktik dan banyak latihan. Melatih keterampilan berbahasa itu pula melatih keterampilan berpikir (Dawson, dalam Tarigan 1994: 1).

Mata pelajaran bahasa Indonesia berdasarkan kurikulum berbasis kompetensi adalah program untuk mengembangkan pengetahuan, keterampilan berbahasa, dan sikap positif terhadap bahasa Indonesia. Menyimak merupakan salah satu bagian dari mata pelajaran Bahasa Indonesia dalam kurikulum berbasis kompetensi. Kurikulum berbasis kompetensi meliputi aspek kemampuan berbahasa. Aspek keterampilan berbahasa meliputi keterampilan mendengarkan, berbicara, membaca dan menulis yang berhubungan dengan ragam sastra. Dalam pembelajaran bahasa dan sastra Indonesia, aspek keterampilan berbahasa dan keterampilan bersastra harus dilakukan secara seimbang.

Sehubungan dengan proses pembelajaran yang berlangsung di SD Negeri 1 Serongga, dari hasil pengumpulan data awaldidapat nilai rata-rata siswa Kelas VI pada mata pelajaran Bahasa Indonesia baru mencapai rata-rata 69,59. Hasil tersebut tentu tidak sesuai dengan harapan keberhasilan pendidikan yang ditetapkan. Tentang pelajaran yang disampaikan, jika pelajaran sempat diterima anak dan belum berhasil, boleh jadi penyebabnya dikarenakan keterbatasan kemauan guru dalam menerapkan semua keilmua yang dikuasai demi pencapaian hasil maksimal dalam pembelajaran. Sedangkan dari pihak siswa banyak dipengaruhi oleh kebiasaan belajar mereka yang rendah akibat pengaruh luar, kemampuan ekonomi orang tua dan kebiasaan belajar yang belum banyak dipupuk. Namun apapun yang menjadi latar belakang permasalahan, apabila hal ini dibiarkan berlarut tentu berakibat tidak baik bagi kelangsungan pendidikan peserta didik dan bagi perkembangan mutu pendidikan bangsa Indonesia.

Karena hal tersebut di atas merupakan sesuatu yang mendesak untuk dipecahkan menuntut guru lebih kreatif dan inovatif menacari jalan keluar dengan melakukan penelitian yang berguna demi meningkatkan kualitas pendidikan di sekolah. Oleh karenanya penelitian ini sangat perlu untuk dilaksanakan.

\section{Metode Penelitian}

Penelitian yang dilakukan termasuk penelitian tindakan. Oleh karenanya, rancangan yang khusus untuk sebuah penelitian tindakan sangat diperlukan. Berdasarkan sudut pandang pencapaian tujuan penelitian, rancanganpenelitian berfungsi sebagai pedoman kerja (peta pedoman pengarahan bagipelaksanaan penelitian). Oleh karenanya, rancangan penelitian harus jelas, singkat dan memberikan petunjuk operasional tentang apa yang sebaiknyadilakukan dan bagaimana cara serta teknik melakukannya. Fungsi lain, rancangan penelitian adalah sebagai rambu-rambu penentuan atau tolok ukurkeberhasilan penelitian yang akan dilaksanakan. Memberikan petunjuk mengenaiukuran-ukuran sampai dimana penelitian yang dilakukan itu dikatakan mencapaihasil yang diinginkan.

Untuk penelitian ini penulis memilih rancangan penelitian tindakan yang disampaikan oleh Mc. Kernan seperti terlihat pada gambar berikut. 
Mc. Kernan

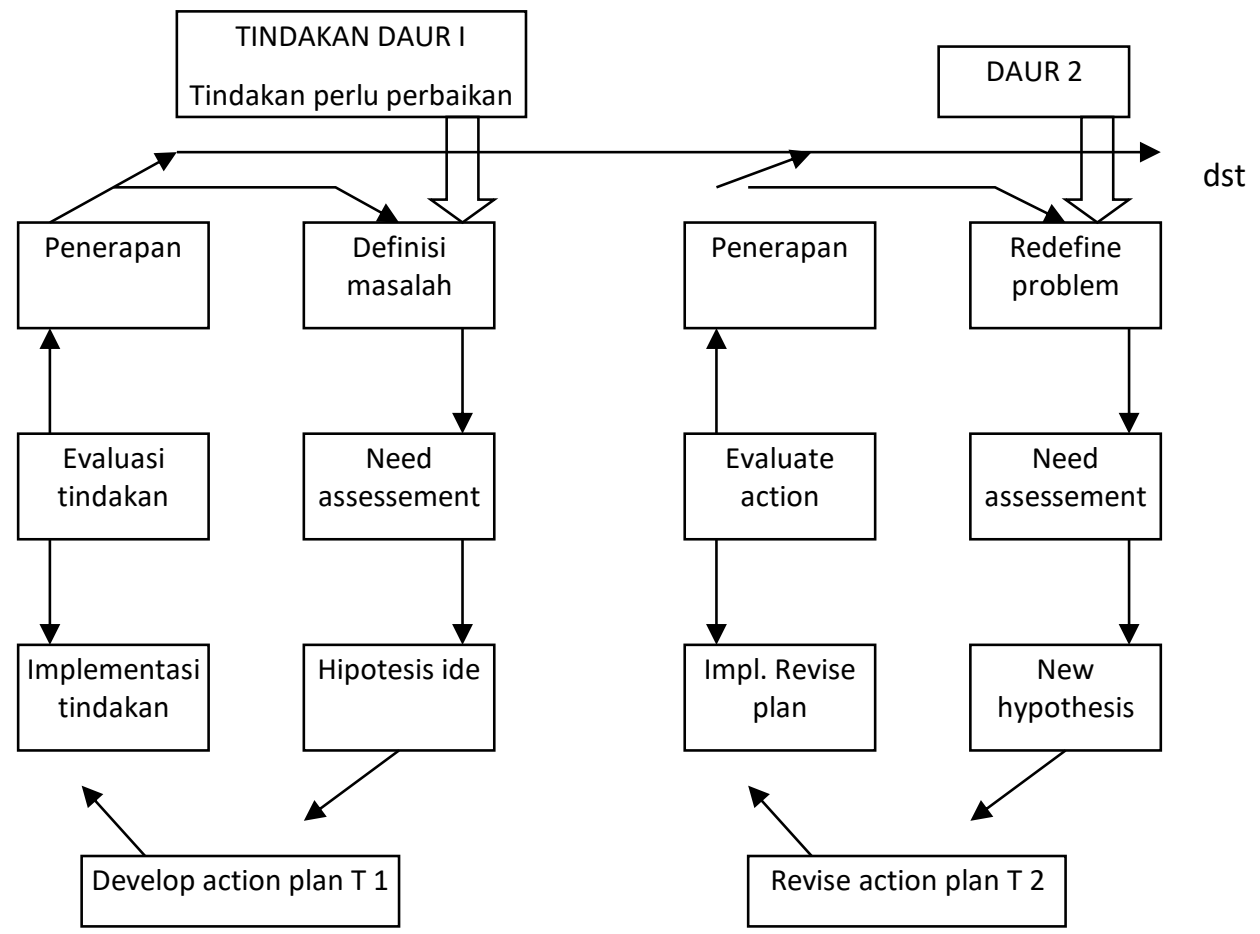

Gambar 01. Penelitian Tindakan Model Mc. Kernan, 1991 (dalam Sukidin, Basrowi, Suranto, 2002: 54)

Prosedur:

- Tindakan daur I: mulai dari definisi masalah, berlanjut ke assessment yang disiapkan, berlanjut ke rumusan hipotesis, berlanjut ke pengembangan untuk tindakan I, lalu implementasi tindakan, evaluasi tindakan berlanjut ke penerapan selanjutnya.

- Tindakan daur II: mulai dari menentukan kembali masalah yang ada, berlanjut ke assessment yang disiapkan, terus ke pemikiran terhadap munculnya hipotesis yang baru, perbaikan tindakan pada rencana ke 2, pelaksanaan tindakan, evaluasi terhadap semua pelaksanaan dan penerapan.

Pengumpulan data dalam penelitian ini menggunakan tes prestasi belajar. Tes prestasi belajar berupa tes soal isian maupaun esay. Untuk menganalisis data hasil penelitian ini digunakan metode deskriptif. Untuk data kuantitatif dianalisis dengan mencari mean, median, modus, membuat interval kelas dan melakukan penyajian dalam bentuk tabel dan grafik.

Indikator keberhasilan penelitian yang diusulkan dalam penelitian ini pada siklus I dan II mencapai nilai rata-rata 75,00 dengan ketuntasan belajar $85 \%$. dengan KKM yang ditetapkan untuk mata pelarajan Bahasa Indonesia pada SD Negeri 1 Serongga adalah 75.

\section{Hasil Dan Pembahasan}

Salah satu indikator keberhasilan dalam pembelajaran adalah prestasi belajar siswa. Djamarah (1994:23) mendefinisikan prestasi belajar sebagai hasil yang diperoleh berupa kesan-kesan yang mengakibatkan perubahan dalam diri individu sebagai hasil dari aktivitas dalam belajar. Kalau perubahan tingkah laku adalah tujuan yang mau dicapai dari aktivitas belajar, maka perubahan tingkah laku itulah salah satu indikator yang dijadikan pedoman untuk mengetahui kemajuan individu dalam segala hal yang diperolehnya di sekolah. Dengan kata lain prestasi belajar merupakan kemampuan-kemampuan yang dimiliki oleh siswa sebagai akibat perbuatan belajar atau setelah menerima pengalaman belajar, yang dapat dikatagorikan menjadi tiga ranah, yakni ranah kognitif, afektif, dan psikomotor. 
Upaya yang dilakukan pada penelitian ini untuk meningkatkan prestasi belajar siswa adalah dengan menerapkan model pembelajaran think-talk-write. Model pembelajaran thinktalk-write (TTW) adalah model pembelajaran yang dapat menumbuh kembangkan kemampuan pemahaman dan komunikasi siswa. Model pembelajaran think-talk-write dikembangkan oleh Huinker dan Laughlin (Yamin dan Ansari, 2008:84) yang dibangun melalui berpikir, berbicara dan menulis. Alur model Think-Talk-Write dimulai dari keterlibatan siswa dalam berpikir atau berdialog dengan dirinya sendiri setelah proses membaca, selanjutnya berbicara dan membagi ide dengan temannya kemudian menulis hasil diskusi. Model ini lebih efektif jika dilakukan dalam kelompok heterogen dengan 3-5 siswa. Dalam kelompok ini semua siswa diminta membaca, membuat catatan kecil, menjelaskan, mendengar dan membagi ide bersama teman kemudian mengungkapkannya melalui tulisan.

Hasil dari penerapan model pembelajaran think-talk-write pada penelitian ini dipaparkan sebagai berikut.

Hasil siklus awal diperolehan nilai rata-rata kelas hasil belajar Bahasa Indonesia masih sangat rendah, yaitu dengan perolehan skor nilai secara klasikal yaitu 2575 dan rata rata kelas 69,59 dimana siswa yang mencapai persentase ketuntasan belajar $37,83 \%$, dan yang tidak mencapai ketuntasan adalah $62,16 \%$, dengan tuntutan KKM untuk mata pelajaran Bahasa Indonesia kelas VI SD Negeri 1 Serongga adalah dengan nilai 75.

Pada siklus I sudah diupayakan untuk perbaikan pembelajaran untuk meningkatkan hasil belajar Bahasa Indonesia dengan menggunakan model pembelajaran Think-Talk-Write. Peneliti telah giat melakukan kegiatan yang susuai dengan kebenaran teori yang ada sehingga peneliti memperoleh hasil yang lebih baik dari proses awal, yaitu dengan rata-rata nilai 74,86 dari jumlah nilai secara klasikal 2770 dari seluruh siswa di kelas $\mathrm{VI}$, dan prosentase ketuntasan belajarnya adalah $72.97 \%$, yang tidak tuntas adalah $27,02 \%$. Hasil ini belum maksimal, karena belum mecapai indikator keberhasilan penelitian yang mencanangkan dengan minimal prosentase ketuntasan belajar $85 \%$.

Dengan tindakan yang sangat maksimal dan pelaksanaan yang betul-betul mengikuti kebenaran teori sesuai dengan model pembelajaran Think-Talk-Write dalam pembelajaran Bahasa Indonesia di kelas VI SD Negeri 1 Serongga, dimana hasil yang diperoleh pada siklus II ini ternyata hasil belajar Bahasa Indonesia meningkat secara signifikan dengan nilai ratarata 81,21 , dan ketuntasan belajarnya adalah 100\%. Dari keseluruhan jumlah siswa, yaitu 37 hanya 37 siswa yanga bisa melampaui atau setara nilai KKM yaitu 75 .

Hasil penelitian ini sesuai dengan hasil penelitian yang dilakukan oleh Winarti (2018) dengan judul Model Pembelajaran Think Talk Write Meningkatkan Prestasi Belajar Mata Pelajaran IPA SD. Hasil penelitian siswa, Pada akhir siklus I siswa tuntas mencapai 22 siswa (85\%). Pada siklus II siswa tuntas mencapai 24 siswa (92\%). Kenaikan atau peningkatan ketuntasan belajar dari siklus I ke sisklus II pertemuan sebanyak $7 \%$. Nilai ratarata kelas yang diperoleh pada siklus I adalah 80. Pada siklus II sebesar 84. Terjadi peningkatan sebesar 4 poin.

Selanjutnya penelitian yang dilakukan oleh Idris (2018) dengan judul Penerapan Model Pembelajaran Think Talk Write Terhadap Aktivitas Belajar Siswa Pada Pembelajaran Matematika Kelas IV Min Bungcala Aceh Besar. Berdasarkan hasil analisis data diperoleh aktivitas guru pada siklus I yaitu $57,33 \%$, pada siklus II mengalami peningkatan yaitu $74,66 \%$, dan meningkat pada siklus III dengan persentase $93,33 \%$. Aktivitas siswa pada siklus I yaitu $74 \%$, pada siklus II mengalami peningkatan yaitu $88 \%$ dan meningkat pada siklus III dengan persentase $94 \%$. Hasil belajar siswa pada siklus I yaitu 56\%, pada siklus II mengalami peningkatan yaitu 68\%, dan meningkat pada siklus III menjadi $84 \%$. Dapat disimpulkan bahwa aktivitas guru dalam mengelola pembelajaran dengan penerapan model pembelajaran Think Talk Write pada siklus I, II dan III mengalami peningkatan. Aktivitas siswa dengan penerapan model pembelajaran Think Talk Write pada siklus I, II dan III mengalami peningkatan. Hasil belajar Matematika siswa kelas IV MIN Bungcala Aceh Besar pada siklus I, II dan III mengalami peningkatan secara signifikan. 


\section{Simpulan}

Setelah dilakukan penggantian metode pembelajaran dari model pembelajaran yang konvensional menjadi model pembelajaran yang konstruktivis yaitu Model Pembelajaran Think-Talk-Write ternyata hasil yang diperoleh meningkat dari data awal rata-rata 69,59 menjadi 74,86 pada siklus I. Setelah perlakuan tindakan dilakukan dengan cukup intentis maka hasil yang diperoleh pada siklus II naik menjadi 81,21 dan mencapai rata-rata sesuai kriteria ketuntasan minimal yang diharapkan. Dengan terjadinya kenaikan prestasi belajar sesuai harapan maka dapat disampaikan bahwa rumusan masalah dan tujuan penelitian sudah mampu meningkatkan prestasi belajar. Dari perolehan bukti tersebut dapat disimpulkan juga bahwa hipotesis penelitian yang diajukan sudah dapat diterima.

\section{Daftar Pustaka}

Ansari dan Yamin. 2008. Taktik Mengembangkan kemampuan Individual Siswa. Jakarta: Putra Grafika.

Badan Standar Nasional Pendidikan. 2006. Panduan Penyusunan Kurikulum Tingkat Satuan Pendidikan. Jakarta: BSNP.Depdiknas. 2007. Peraturan Menteri Pendidikan Nasional No. 16 tahun 2007 tentang Kualifikasi Akademik dan Kompetensi Guru. Jakarta: Depdiknas.

Basrowi dan Sukidin. 2002. Metode Penelitian Kualitatif Perspektif Mikro. Surabaya. Insan Cendikia.

Depdiknas. 2005. Peraturan Pemerintah Nomor 19 tahun 2005 tentang Standar Nasional Pendidikan. Jakarta: Depdiknas.

Depdiknas. 2007. Peraturan Menteri Pendidikan Nasional No. 41 tahun 2007 tentang Standar Proses Pendidikan Dasar dan Menengah. Jakarta: Depdiknas.

Dimyati dan Mudjiono. 2001. Belajar dan Pembelajaran. Jakarta: Dirjen Dikti.

Djamarah, Syaful Bahri. 2002. Prestasi Belajar dan Kompetensi Guru. Surabaya: Usaha Nasional.

Idris, Tasnim. 2018. Penerapan Model Pembelajaran Think Talk Write Terhadap Aktivitas Belajar Siswa Pada Pembelajaran Matematika Kelas IV Min Bungcala Aceh Besar. Pionir Jurnal Pendidikan Volume 7 Nomor 1.

Rohani, Ahmad. 2004. Pengelolaan Pengajaran. Jakarta: Rineka Cipta.

Sahertian, Piet A \& Ida Aleida Sahertian.1992. Supervisi Pendidikan Dalam Rangka Program Inservice Education. Jakarta: Rineka Cipta.

Sahertian, Piet A. 1994. Profil Guru Prefesional. Yogyakarta: Andi Offset.

Sardiman, A.M. 1988. Interaksi dan Motivasi Belajar-Mengajar Pedoman bagi Guru dan Calon Guru. Jakarta: Rajawali Pers.

Sukmadinata, Nana Syaodih. 2007. Metode Penelitian Pendidikan. Bandung: PT. Remaja Rosda Karya.

Tarigan. 1994. Menulis Sebagai Suatu Keterampilan Berbahasa. Bandung: Angkasa.

Winarti, Asih. 2018. Model Pembelajaran Think Talk Write Meningkatkan Prestasi Belajar Mata Pelajaran IPA SD. Jurnal Pendidikan: Riset \& Konseptual Vol. 2 No. 3. 